\title{
The Banality of Gilding: Innocuous Materiality and Transatlantic Consumption in the Gilded Age
}

Paul R. Mullins \& Nigel Jeffries

2012

International Journal of Historical Archaeology

Vol. 16 No. 4

[Author's version. Final published version available from: http://dx.doi.org/10.1007/s10761-012-0206-x]

\begin{abstract}
This paper examines Gilded Age affluence by focusing on apparently inconsequential decorative goods and assessing how such goods were part of shared transatlantic patterns that reached beyond the Gilded Age and the confines of urban America. The paper focuses on figurines recovered from $19^{\text {th }}$-century sites in London and underscores how the American Gilded Age amplified many early $19^{\text {th }}$-century material patterns and ideological practices that were wellestablished in the United Kingdom and continued after the height of Gilded Age affluence. This study examines the symbolism of such aesthetically eclectic goods and focuses on the socially grounded imagination that was invested in them borrowing from dominant ideologies and idiosyncratic personal experiences alike.
\end{abstract}

\section{Acknowledgments}

Mullins' research in the London Archaeological Archive and Research Center (LAARC) was funded by an Indiana University Overseas Research Grant from the Office of the Vice President of International Affairs. While working at the LAARC, much of this analysis was discussed with Rupert Featherby and Alastair Owens. Thanks to the many colleagues who have shared their data and discussed these ideas, including Emma Dwyer, Julian Harrop, Mark Leone, Ralph Mills, Chuck Orser, Bob Paynter, Adrian and Mary Praetzellis, Jim Symonds, Mark Warner, and Jane Webster. Any shortcomings of the paper are entirely our own fault despite so much good advice.

Author's version. Final version published as:

Mullins, P.R., \& Jeffries, N. (2012). The banality of gilding: Innocuous materiality and transatlantic consumption in the gilded age. International Journal of Historical Archaeology, 16(4), 745-760. http://dx.doi.org/10.1007/s10761-012-0206-x 
The Banality of Gilding: Innocuous Materiality and Transatlantic Consumption in the Gilded Age

Paul R. Mullins ${ }^{1}$

Nigel Jeffries ${ }^{2}$

May 3, 2012 SUBMISSION DRAFT sans images

${ }^{1}$ Department of Anthropology, Indiana University-Purdue University, Indianapolis, Cavanaugh Hall 413B, Indianapolis, Indiana 46202 USA

${ }^{2}$ Museum of London Archaeology, Mortimer Wheeler House, 46 Eagle Wharf Road, London N1 7ED, UK

Author's version. Final version published as:

Mullins, P.R., \& Jeffries, N. (2012). The banality of gilding: Innocuous materiality and transatlantic consumption in the gilded age. International Journal of Historical Archaeology, 16(4), 745-760. http://dx.doi.org/10.1007/s10761-012-0206-x 


\begin{abstract}
This paper examines Gilded Age affluence by focusing on apparently inconsequential decorative goods and assessing how such goods were part of shared transatlantic patterns that reached beyond the Gilded Age and the confines of urban America. The paper focuses on figurines recovered from $19^{\text {th }}$-century sites in London and underscores how the American Gilded Age amplified many early $19^{\text {th }}$-century material patterns and ideological practices that were well-established in the United Kingdom and continued after the height of Gilded Age affluence. This study examines the symbolism of such aesthetically eclectic goods and focuses on the socially grounded imagination that was invested in them borrowing from dominant ideologies and idiosyncratic personal experiences alike.
\end{abstract}

Keywords

Consumption, Affluence, Figurines, Atlantic World

"Material for thought": Consumption, Gilded Age Affluence, and Household Materiality In 1876 Henry Ward Beecher greeted the United States' centennial by celebrating a prosperous republic in which "there is more material for thought, for comfort, for home, for love, to-day, in the ordinary workingman's home, than there was a hundred years ago in one of a hundred rich men's mansions and buildings" (Orvell 1989, pp. 46-47). The material forms 
taken by Gilded Age affluence included many ostentatious objects, and period observers and scholars alike often have focused on the most astounding material goods found in elite homes. Beecher himself had a spectacular household assemblage of figurines and decorative goods that was auctioned in November, 1887. Many comparable goods evoking affluence and worldliness were found in homes throughout the Atlantic World, but Beecher's collection contained exceptionally expensive examples of all the goods he had invoked in his Centennial address: 3024 books, a massive collection of oil paintings, several thousand engravings, 30 antique Oriental rugs, a scatter of stuffed animals, and hundreds of pieces of furniture went under the auctioneers' gavel. The assemblage was composed of thousands of decorative goods with no concrete function besides aesthetic display, including figurines and statues as well as goods such as Asian ceramics that were generally reserved for display in bourgeois homes.

It was precisely this sort of pretentious material wealth and the imperative to consume that Mark Twain and Charles Dudley Warner first ridiculed in The Gilded Age. Twain and Warner's analysis posed life in the wake of the Civil War as contrived "gilding" masking an inferior reality. Histories of the Gilded Age have often followed Twain and Warner's rhetorical lead, painting it as a period of aggressive capitalist accumulation and growth that, in Vernon Louis Parrington's words, had "no social conscience, no concern for civilization, no heed for the future of the democracy it talked so much about." Parrington (1927) characterized the Gilded Age as crass material opportunism, writing in 1927 that Gilded Age society was a marked 
contrast "from the sober restraints of aristocracy, the old inhibitions of Puritanism, the niggardliness of an exacting domestic economy ... and with the discovery of limitless opportunities for exploitation it allowed itself to get drunk." Thorstein Veblen's (1899) analysis of conspicuous consumption in Chicago was among the best-known studies linking consumption to Gilded Age social life, and he painted a picture of consumers driven by invidious status hierarchies that hearkened back to a ceremonial past. Veblen $(1899$, p. 85$)$ noted that "No class of society, not even the most abjectly poor, forgoes all customary conspicuous consumption. ... Very much squalor and discomfort will be endured before the last trinket or the last pretense of pecuniary decency is put away." Veblen departed from dominant neoclassical economic theories that goods have a specific utility and consumers make rational, independent decisions based on all possible information. Instead, Veblen argued that consumers had always acquired things as mechanisms to demonstrate social status. Writing in the midst of an especially active consumer metropolis, Veblen coined the notion of conspicuous consumption to explain the high-style materialism that he witnessed in late nineteenth-century Chicago. Veblen argued that consumption of desirable goods was public evidence of a consumer's wealth and their mastery of social discipline and style (Veblen 1899, pp. 46-47). Gilded Age consumption and broader Victorian materialism certainly included ostentatious symbols of excess and some deluded aspirations to wealth, but focusing on these factors alone risks ignoring the rich meanings of the mass-produced things crowding gilded age. International Journal of Historical Archaeology, 16(4), 745-760. http://dx.doi.org/10.1007/s10761-012-0206-x 
transatlantic households. It is easy enough to ignore such material goods since many of the material forms fueled by prosperity were at least superficially mundane. Beecher himself argued that an array of rather prosaic goods should be in all homes, intoning that "The laborer ought to be ashamed of himself ... who in 20 years does not own the ground on which his house stands and ... who has not in that house provided carpets for the rooms, who has not his China plates, who has not his chromos, who has not some picture or portrait hanging upon the walls, who has not some books nestling on the shelf, who has not there a household he can call his home, the sweetest place upon the earth. This is not the picture of some future time, but the picture of to-day, a picture of the homes of the workingmen of America" (Orvell 1989, pp. 4647). The goods Beecher singled out were all quite common: carpets, tablewares, chromolithographs, and books could be found in almost every household and were readily obtainable for a vast range of consumers. Beecher's advice to stock homes with an array of rather prosaic things was somewhat in contrast to his own household assemblage, which was a spectacular cascade of symbols that invoked ideological visions of nature, history, culture, nationalism, and wealth. Most homes were outfitted with comparably quotidian decorative objects, but those goods included spectacular aesthetics not much different than those in Beecher's home. Indeed, across the Atlantic World $19^{\text {th }}$-century consumers embraced a materiality that employed spectacular symbolism invoking culture, heritage, domesticity, and a host of rather ill-defined social beliefs.

Author's version. Final version published as:

Mullins, P.R., \& Jeffries, N. (2012). The banality of gilding: Innocuous materiality and transatlantic consumption in the gilded age. International Journal of Historical Archaeology, 16(4), 745-760. http://dx.doi.org/10.1007/s10761-012-0206-x 
This paper focuses on a collection of decorative figurines recovered from $19^{\text {th }}$ century archaeological sites in London and examines how period commentators on each side of the Atlantic defined their meaning. Some of these figurines are in chronological contexts that are not strictly Gilded Age assemblages (typically defined as circa 1870-1893), but many identical motifs are found in earlier and later contexts alike. The Gilded Age is a term reserved for American contexts, but we want to argue here that many of the patterns in Gilded Age decorative materiality and broader consumption patterns were transatlantic phenomena. Consequently, we are interested in the ways that Gilded Age ideologies amplified long-term material styles outside late- $19^{\text {th }}$ century American elite contexts as they also led to a continuation of comparable decorative aesthetics afterward. Comparing objects outside American contexts alone reveals broad Atlantic World patterns in the relationship between everyday material goods and social and material ambitions that extended beyond a narrowly defined American urban elite.

"A great store of shepherdesses": The Aesthetics of Bric-a-Brac

Figurines were mass-produced by virtually all English potteries from the $18^{\text {th }}$-century onward, and nearly anything that could be modeled appeared as a figurine at some point. In 1851 Henry Mayhew (1851, p. 354) decried the offerings of typical London figurine shops, describing them as a "great store of shepherdesses, or greyhounds of a gamboges color, of 
what I heard called 'figures' (allegorical nymphs with and without birds or wreaths in their hands), very tall-looking Shakspeares [sic] (I did not see one of these windows without its Shakspeare, a sitting figure), and some 'pots' which seem to be either shepherds or musicians." A shepherd figure much like the ones Mayhew derided was excavated from the Jacob's Island site in the London Borough of Southwark. The Jacob's Island figure had only its base surviving, but the base bore the identification of it as a "SHEPERD" (sic). In the US and UK alike such broadly defined motifs invoked apprehensions of urbanization and labor by celebrating a romanticized pastoral heritage, yet the ambiguity of the motif and ideological references, the small scale and unobtrusiveness of the figurine, and the modest cost of such decorative goods made them especially rich symbolic vehicles. Decorative goods like the shepherd figurine occupy an interesting but not wholly unique position in commodity symbolism. On the one hand, like many commodities, figurines are physically prosaic forms that reside beneath critical awareness (cf. Mills 2010). To some scholars they appear to invoke only the most fundamental ideological messages about wealth, heritage, nature, and similarly broad discourses; they are simply viewed as yet another class of goods distinguished by their function; their insignificant cost (in most cases) renders them inconsequential; or very modest excavated quantities of brica-brac makes them seem symbolically insignificant. Many observers (and some archaeologists) have been unable to see past the seemingly crass surface of gilding, reducing the flood of inexpensive decorative objects in $19^{\text {th }}$-century homes to hollow claims to socioeconomic status gilded age. International Journal of Historical Archaeology, 16(4), 745-760. http://dx.doi.org/10.1007/s10761-012-0206-x 
or insignificant aesthetic displays. Consequently, there is a tendency to see them as utterly banal in terms of their physical and aesthetic presence and, by extension, their symbolic if not political impacts.

On the other hand, though, figurines often appeared in ambiguous if not spectacular stylistic forms that sparked a very wide range of public discourses and consumer meanings. Period observers often commented on figurines and household aesthetics throughout the $19^{\text {th }}$ century, and Gilded Age analyses are rife with dense material descriptions of the pretentious forms taken by Americans' sudden wealth. A rich late- $19^{\text {th }}$ century literature on gilding wrestled with the enigma of how social relations shaped the meaning of things, pushing beyond simply seeing their meanings expressed as prices (Richards 1990, pp. 263-264). A flood of thinkers pondered material desire, the "signifying power" of material goods, and the ways in which consumers projected their imaginations onto material goods (Pykett 2003, p. 1; Mills 2008). This rich symbolism found an especially receptive consumer audience in post-Civil War America, but similar if not identical decorative goods were marketed and consumed quite extensively throughout the Atlantic World before the 1870s. In their 1897 survey of household material culture, Edith Wharton and Ogden Codman (1897, p. 83) argued for common bric-abrac styles throughout the Atlantic World, indicating that "the reaction from the bare stiff rooms of the first quarter of the present century - the era of mahogany and horsehairresulted, some twenty years since, in a general craving for knick-knacks; and the latter soon 
spread from the tables to the mantel, especially in England and America." Indeed, the consumption of such goods outside the US suggests that many of the consumer patterns linked to wealth and social discipline in Gilded Age America extended in some forms over most of the "Iong $19^{\text {th }}$ century" and outside the provincial boundaries of the US alone.

Decorative figurines and similar household goods had been mass-produced since the $18^{\text {th }}$ century. A 1917 collector's survey of $18^{\text {th }}$-century figurines indicated that in the second half of the $18^{\text {th }}$ century "about twenty of the Staffordshire potters engaged in this business. Pastoral groups and animals were favorites with them, and also scriptural and pseudo-Classical subjects. The Flight into Egypt, Elijah and the Widow, busts of Franklin, Shakespeare, Milton, and Falstaff, Toby jugs, cavaliers, shepherdesses, and dogs were all popular, and indicate the general scope of subjects" (Fearing 1917, p. 82). Such decorative goods were in most $19^{\text {th }}$ century domestic assemblages. In 1825, for instance, a criminal case was lodged in London's Old Bailey by laborer Robert Williams, who had left a trunk in the home of his landlord William Gerrard only to find that Gerrard and two women had claimed it while Williams was gone for an extended absence. The trunk included a modest range of goods that composed all of Williams' earthly possessions, including eight "chimney ornaments" valued at four shillings (Old Bailey 1825). The trunk held 23 groups of items including a tea pot (value three shillings), three wine glasses (1 s), 15 plates (two s), three pillows (6 s), a coat (value 25s), seven yards of silk (value 11s), a petticoat (value 20s), two prints (value 3d), two spoons (value 6d), and a pair of sugar 
tongs (value $6 \mathrm{~d}$ ). The ornaments apparently held some idiosyncratic if not especially significant exchange value in an otherwise modest laborers' assemblage long before the zenith of bric-abrac consumption.

The volume of figurines increased dramatically in the $19^{\text {th }}$ century, when they were marketed in various times and places as "chimney ornaments," "cottage ornaments," "knick knacks," or lumped within the category of "bric-a-brac." Style ideologues routinely lampooned mass-produced figurines, but that advice was apparently ignored by most households, because decorative goods were found in at least modest quantities in virtually every household through most of the $19^{\text {th }}$ century. For instance, in 1870 the British journal The Builder (1870, pp. 402403) indicated that "always to be found in the room of the poorest and humblest, are what are termed 'chimney ornaments.' ... Figures in coarse china-ware, very gorgeously coloured, animals of different sorts, grotesques somehow contrived so as not to be grotesque at all, but only utterly unmeaning and silly; imitation model clocks, a whole warehouse of stupidities, are common end to be seen everywhere, and are eagerly bought and carefully displayed, and always on view, for there is no getting away from them." Collector Virginia Robie's (1912, pp. 75-76) survey of figurine motifs indicated that "your chimney ornament may be anything from a woolly china dog to a brightly painted villa. It may be common Staffordshire crockery, or a really fine porcelain; it may be a work of art, or an atrocious daub. If it is a real cottage specimen, it is quite apt to be a daub, for the cottage ornament pure and simple was of humble origin, made gilded age. International Journal of Historical Archaeology, 16(4), 745-760. http://dx.doi.org/10.1007/s10761-012-0206-x 
of coarse clay, decorated by a potter whose education, if he had any, was not along art lines, and turned out to sell at two-and-six apiece; sometimes for one-and-six. But two shillings and sixpence was, and is, quite a sum to an English cottager. It ought to buy a very respectable china cow, and, to the potter's credit, it may be said that it did." European potteries produced figurines, too, and in 1870 The Builder (1870, p. 403) intoned that "It may not here be out of place to inform or remind the intelligent reader that there are 'warehouses' in the east end of London which regularly import by wholesale cargoes of ornaments of the kind mentioned. They would seem to be manufactured in France and Germany, and are the production, for the most part, of children working, of course, under a regular-system of manufacture, the object passing from hand to hand as it goes on to completion.... The workshops are the south of France and Germany, but the markets England and America."

As Virginia Robie (1912, p. 76) acknowledged in 1912, most such goods were quite inexpensive, and this was the case for most figurines throughout the $19^{\text {th }}$ century. For instance, an 1899 "fancy goods" price list from the London wholesaler T.M. Whitton and Sons (1899) inventoried a vast range of motifs designed to retail at six pence, including "New Blue Glazed Tall Figures," "New Assorted China Dogs," “New 10-inch Tall Glazed Figures," “Negro Umbrella Figures," "Nodding Chinaman Figure," and "Large Cats and Dogs." Such goods could be acquired in a broad range of market spaces. In her 1904 survey of life in $19^{\text {th }}$-century Surrey, Gertrude Jekyll (1904, p. 119) indicated that "I can remember when this class of chimney 
ornament was sold at country fairs, such as the yearly fair at St. Catherine's Hill near Guildford .... The same kind of ornament was also to be bought in china shops, as well as a better type, like second-rate Chelsea."

In some ways, figurines invoked the pretentious material displays and extravagant aesthetics of elite Victorian households that reached a pinnacle in the Gilded Age. Period observers like Mark Twain were often suspicious of the ostentatious decorative affluence found in many American homes. For many of them, this material "gilding" was pure artifice that aspired to make its consumers appear worthy of social privilege, and for many thinkers that contrived privilege inelegantly revealed the absence of substance beneath. The notion of gilding drew a distinction between, on the one hand, appearances of wealth, taste, or social privilege and, on the other hand, realities in which dramatic materiality masked character shortcomings, modest material standing, or an absence of educated style and taste. For instance, William Dean Howells' 1889 novel A Hazard of New Fortunes detailed a "drawingroom ... delicately decorated in white and gold, and furnished with a sort of extravagant good taste; there was nothing to object to the satin furniture, the pale, soft, rich carpet, the pictures, and the bronze and china bric-a-brac, except that their costliness was too evident; everything in the room meant money too plainly, and too much of it" (Howells 1889, p. 199). The drawing room's visitors concluded that "this tasteful luxury in nowise expressed their civilisation" (Howell 1889, p. 199). In 1894 novelist Sarah Grand (1894, p. 194) wove a similar tale, detailing gilded age. International Journal of Historical Archaeology, 16(4), 745-760. http://dx.doi.org/10.1007/s10761-012-0206-x 
a home that "was crowded now to suffocation with curtains, cushions, couches, ottomans, and easy chairs, upholstered in the modern manner with mere trivialities of a costly fashion, devoid of association with the past, and not likely or even intended to last into any distant future. It was decorated, too, in excess with pictures, statues, china, arms, and ornaments of every sort, stuck any and everywhere till the eye was satiated. .... It was a house furnished to death."

These eclectic and striking aesthetics in paradoxically prosaic items often forced observers to contemplate and question their own preconceptions about consumers. In 1885, for example, Charles Eyre Pascoe's (1885, p. 293) guide to London devoted a whole chapter to bric-a-brac shops, acknowledging that "most of us, from the highest to the lowest, have a liking for such things; the chimneypiece of the humblest cottage is seldom destitute of ornament of some kind." Yet Pasco admitted that he "was once surprised to find in a stuffy back room of a small tenement house in a London suburb, chiefly inhabited by working-men, a remarkable collection of bric-a-brac-such a collection, indeed, as would have brought no discredit to a much more cultivated connoisseur." Ideologically, all consumers were expected to make the effort to follow household decorative disciplines, but for various class, racial, and ethnic reasons ideologues assumed that most consumers could not reproduce dominant standards. Consequently, stylish decorative goods often registered with observers who recognized that such goods signaled social aspirations if not a circumspect foothold in consumer society. 
Novelist Edith Wharton and architect Ogden Codman Jr.'s 1897 study The Decoration of Houses spent a whole chapter exorcising most bric-a-brac from the American and British parlor alike, and they noted the ways gilding had lost its symbolic power as the $20^{\text {th }}$ century approached. They suggested that the "deterioration in gilding is one of the most striking examples of the modern disregard of quality and execution. In former times gilding was regarded as one of the crowning touches of magnificence in decoration, was little used except where great splendor of effect was desired, and was then applied by means of a difficult and costly process. To-day, after a period of reaction during which all gilding was avoided, it is again unsparingly used. ...The result is a plague of liquid gilding" (Wharton and Codman 1897, p. 193). For Wharton and Codman, gilding invoked genuine material and symbolic wealth, and its reach into commonplace goods and everyday domestic spaces erased its capacity to confirm such social and material standing, arguing that "in former times the expense of good gilding was no obstacle to its use, since it was employed only in gala rooms, where the whole treatment was on the same scale of costliness: it would never have occurred to the owner of an average-sized house to drench his walls and furniture in gilding, since the excessive use of gold in decoration was held to be quite unsuited to such a purpose. Nothing more surely preserves any form of ornament from vulgarization than a general sense of fitness” (Wharton and Codman 1897, p. 193). gilded age. International Journal of Historical Archaeology, 16(4), 745-760. http://dx.doi.org/10.1007/s10761-012-0206-x 
Animal figurines were probably the most common figurine motif. Many of the animals rendered in ceramic figurines were domesticated pets, often representing on the mantelpiece the same animals that might also inhabit Victorian homes. Nearly 100 figurines from London archaeological sites were analyzed for this study, and not one depicts a wild animal, instead portraying dogs, sheep, and a host of domesticated animals including house pets and livestock alike. A typical whiteware figurine recovered from a mid- $19^{\text {th }}$ century cesspit on Randall Row in the London Borough of Lambeth includes the remains of a seated dog alongside a foot that was almost certainly understood to be the dog's owner (Jeffries 2006, p. 284). Such human and animal relationships were widely believed to have domesticating effects on people. In 1868 , for instance, Josepha Buell Hale (1868, p. 244) repeated a view of pets that emerged in the first half of the $19^{\text {th }}$ century (cf. Grier 1999), indicating that "Home-life is the place for all innocent loves; and, when the love of pet animals can be judiciously cultivated, it leads to the love of natural history and intellectual improvement, as well as to thoughtful tenderness and moral sensibility." Egerton Leigh $(1859$, p. 6$)$ agreed that the "love of Pets is one of the flowers of civilization, a feeling either openly apparent or lying dormant until warmed into existence by circumstances .... there is something humanizing in a Pet, which makes the heart open to the genial warmth of kindness, like the rose bud expanding its long folded leaves when kissed by the sunbeam." 
Many figurines did not depict a human with the animal, yet even in those cases the central relationship between pets and humans--and the ways both could be domesticated--was the central implied subject of many animal figurines. For example, a dog figurine from the Chelsea Academy site in the Royal Borough of Kensington and Chelsea sits on its haunches resplendent in a sweater with a black collar: impeccably dressed, motionless, and utterly disciplined, the dog provided a model for behavior that thwarted the dog's natural instincts, just as many households hoped their human family members would curb their own desires and behaviors as well (Cetera 2008). Figurines of sheep and lambs were likewise common. A typical example was recovered from the Queensborough House site in Lambeth with a nowfragmented human figure alongside a lamb docilely resting at the figure's feet. Such motifs invoked a mostly fictive pastoral past that was significant as a contrast to the defamiliarization of cities and factory labor, and on a London mantel the symbols of agrarian life were clear contrasts with everyday urban life in the metropolis. This approaches figurines as a symbolic retreat from everyday experience, albeit one that casts such experience in a purely escapist if not ideological form.

"Ambitious borrowed decorations": Art, History, and Bric-a-Brac

Disingenuous ideologues constantly pressed to elevate household aesthetics and fortify genteel standards by championing a variety of stylish and often "artistic" decorative goods. 
Much of this overwrought commentary inelegantly attempted to patrol class divisions and ensure that working people and the elite were distinguished by material goods. In 1846, for instance, Andrew Jackson Downing wrote in The Horticulturist (1846, p. 107) that "the mansion of the wealthy proprietor, which is filled with pictures and statues, ought certainly to have a superior architectural character to the cottage of the industrious workingman, who is just able to furnish a comfortable home for his family. While the first is allowed to display even an ornate style of building, which his means will enable him to complete and render somewhat perfect-the other cannot adopt the same ornaments without rendering a cottage, which might be agreeable and pleasing, from its fitness and genuine simplicity, offensive and distasteful through its ambitious borrowed decorations"(cf. Downing 1856, p.247). This midcentury commentary pointed toward many subsequent ideologues' apprehension that massproduced goods risked erasing the visible class distinctions once rendered in the material world. That apprehension likely fueled the volume of commentary that criticized figurines and most mass-produced decorative material culture.

Ideologues' critique of everyday materiality routinely celebrated household "art." In 1870, for example, The Builder moaned that "It will surely then be seen that the art of common things is a matter of importance and interest, and the chimney ornaments on the chimney shelf of a working man's room, and the pictures hung round the walls of it, may come to be tests of his educational advancement; and perhaps the Government inspector himself may actually find gilded age. International Journal of Historical Archaeology, 16(4), 745-760. http://dx.doi.org/10.1007/s10761-012-0206-x 
out what sort of education the workman's family of sons and daughters are receiving by a simple inspection of the chimney ornaments and pictures in his possession, and even get in time an idea of art himself" (The Builder 1870, p. 402). Nineteenth-century decorative ideologues routinely counseled consumers to stock their homes with "art," an ambiguity that framed a complicated ideological terrain. When invoked in material ideologues' thought, "art" routinely included both purely ornamental objects (e.g., figurines, chromolithographs) as well as functional goods (e.g., lamps, clocks); it clouded the distinction between a unique work of art and a mass-manufactured commodity; and it included both contemporary objects and genuine antiquities. In 1897, Edith Wharton and Ogden Codman (1897, p. 186) struggled with the ways cost shaped aesthetic meaningfulness, arguing that "though cheapness and trashiness are not always synonymous, they are apt to be so in the case of the modern knick-knack. To buy, and even to make, it may cost a great deal of money; but artistically it is cheap, if not worthless; and too often its artistic value is in inverse ratio to its price. The one-dollar china pug is less harmful than an expensive onyx lamp-stand with moulded bronze mountings dipped in liquid gilding." This position was typical of late- $19^{\text {th }}$ century stylistic critiques that aspired to remove clutter from Victorian parlors, and it also launched a complicated critique of cost-status. Wharton and Codman (1897, p. 186) argued that "it is one of the misfortunes of the present time that the most preposterously bad things often possess the powerful allurement of being expensive. One might think it an advantage that they are not within every one's reach; but, as a matter of fact, gilded age. International Journal of Historical Archaeology, 16(4), 745-760. http://dx.doi.org/10.1007/s10761-012-0206-x 
it is their very unattainableness which, by making them more desirable, leads to the production of that worst curse of modern civilization-cheap copies of costly horrors." This was a lamentation about the ways overdone elite styles were reproduced in mass-produced goods, and they dismissively concluded that "it seems improbable that our commercial knick-knack will ever be classed as a work of art" (Wharton and Codman 1897, p. 184). In 1870, The Builder (1870, p. 403) pondered what exactly constituted art, suggesting that "if among the very worst of these trumpery 'ornaments' we take the vilest and the most worthless and the cheapest,say a small earthenware figure of a man and dog, the man with a daub of red, and the dog with a daub of blue, and compare such with a very expensive modern line engraving of a like subject,-I say it would puzzle the most expert of art analysts or art critics to determine with accuracy which of the twain is the emptiest and the most artistically worthless. A real and practical change in art and in the practice of it will certainly come about when the time shall come for even the commencement of a new order of things on the 'chimney-shelf' and walls of a common room!"

Wharton and Codman expressed a commonplace affection for the antique, which became perceived as "real" and in opposition to the artificial commodity. They concluded that the debasement of art reflected that "the substitution of machine for hand-work has made possible the unlimited reproduction of works of art; and the resulting demand for cheap knickknacks has given employment to a multitude of untrained designers having nothing in common 
with the virtuoso of former times" (Wharton and Codman 1897, p. 191; emphasis in original).

Bric-a-brac included some objects that reproduced classical antiquities, but some of these figurines were expensive and do not appear in many archaeological assemblages. The Spitalfields Market site in London included a caneware Triton candlestick, a relatively typical example of late- $18^{\text {th }}$ and early $19^{\text {th }}$-century figurines incorporating classical motifs. The caneware Triton was found alongside a small range of complete mid 19th-century ceramics in a cellar that served a public house at no. 9 Crispin Street (Holder and Jeffries in prep). The Greek god Triton was manufactured in basalt, jasper, and other refined wares by Wedgwood beginning about 1770, but the Spitalfields example is unmarked, and the same design was produced by other potters including Enoch Wood and James Caldwell (circa 1790-1818). By the second half of the $19^{\text {th }}$ century most figurines reproducing historical aesthetics liberally borrowed from a breadth of historical styles. Rather than clearly invoke some concrete mythological reference like Triton or a real historical person like Napoleon, most figurines included no references to concrete artwork, symbols, periods, or personalities. For instance, the Albert Embankment site in Lambeth included a typical later-19 ${ }^{\text {th }}$ century figurine in clothing that was certainly not $19^{\text {th }}$-century garb, but it has no especially clear referent to historical dress: With a button jacket rendered in orange and brown polychrome dots and a flowing purple sash dropping from beneath the jacket, the figure might well be a pseudo-historical reference, even though the actual referent is not clear and may never have existed in the minds 
of its makers. Other motifs were more clearly period references, but their symbolism was ambiguous. For example, the Albion Brewery in Whitechapel located in London's East End included amongst its post-1830 backfill a seated equestrian figure that evokes the ways $17^{\text {th }}$ century garb was being defined in mid $19^{\text {th }}$-century novels like The Three Musketeers, which was first serialized in 1844 and appeared in English two years later. The Albion figurine is of a male in knee-height boots, a broad hat, and a bold mustache sitting astride a horse now gone, invoking the historical symbolism of $17^{\text {th }}$-century France as well as the class dimensions of horseback riding. The most productive figurines worked not necessarily because they invoked a clear reference but because they instead provided ambiguous jumping-off points for consumers who might imagine any number of meanings for such symbols.

Rethinking Gilded Affluence and Small Things

The eclectic motifs of figurines and ornamental household goods were highly prized by consumers across a social and economic spectrum spanning the Atlantic World, yet they have been largely ignored by archaeologists. These rather mundane decorative goods found throughout the Atlantic World provide interesting challenges to conventional archaeological insight. Historical archaeologists have long focused on three dimensions of material symbolism that are complicated by Victorian bric-a-brac. First, archaeologists have fixated on relative wealth, literally how an assemblage confirms a household's standing in an economic 
continuum. Most figurines were quite inexpensive, though, and the expense of outfitting even a whole home in figurines was not significant. Analysis of the Gilded Age often stresses rapidly expanding affluence and the material and documentary data reflecting increased wealth, but consumers might gain a foothold in this newfound affluence without necessarily being especially wealthy.

Second, much archaeological thought has pondered the ways consumers ostensibly "display" their affluence and mastery of social disciplines. Archaeologists have long aspired to divine how consumers use goods to demonstrate wealth and mastery of dominant social codes to peers. Figurines would seem ideal evidence to probe this question, since they were ornamental objects meant to be exhibited in some domestic context, and they did often invoke affluence and ideological symbolism in various forms. However, this focuses on consumption as instrumentally "other-directed," casting materiality as a presentation of oneself to others, essentially mirroring who we are. This risks ignoring the imaginative, inchoate, and personal dimensions of material consumption, those dimensions of consumption that are about who we wish we are.

Third, Victorian and Gilded Age decorative commodities complicate simplistic notions of material representation that pose goods merely as reflective mechanisms that publicly communicate underlying social values and ideological meanings, and in fact the challenges dealt by figurines are common to most commodities. Mark Leone (1992, p. 130; 1998, p. 57) 
distinguishes between recursive and reflective theories of material symbolism, and recursive materiality fits the symbolism of bric-a-brac especially well. Leone argues that material culture is recursive in its capacity to actively form meaning, which he opposes to a purely reflective symbolism that merely mirrors behaviors and represents instilled meanings. This notion of a recursive symbolism works quite well for figurines, which were not necessarily intended to represent anything particularly concrete. Perhaps the "gilding" itself--the very appearance of many commodities and their capacity to charge consumers' imaginations--was what made some goods meaningful. This notion of an active symbolism formed by consumers diverges from approaching figurines in terms of their capacity to strategically display affluence, ideological incorporation, or any other number of dimensions of identity. Rather than focus simply on what decorative material goods-or for that matter all commodities-- instrumentally represented, we might instead focus on the apparently superficial gilding itself, examining how the surface aesthetics of decorative goods assumed meaning and cannot be approached simply as mechanisms that represented other meanings. 


\section{Acknowledgements}

Mullins' research in the London Archaeological Archive and Research Center (LAARC) was funded by an Indiana University Overseas Research Grant from the Office of the Vice President of International Affairs. While working at the LAARC, much of this analysis was discussed with Rupert Featherby and Alastair Owens. Thanks to the many colleagues who have shared their data and discussed these ideas, including Emma Dwyer, Julian Harrop, Mark Leone, Ralph Mills, Chuck Orser, Bob Paynter, Adrian and Mary Praetzellis, Jim Symonds, Mark Warner, and Jane Webster. Any shortcomings of the paper are entirely our own fault despite so much good advice. 


\section{References}

Ames, K. L. (1978). Meaning in Artifacts: Hall Furnishings in Victorian America. Journal of Interdisciplinary History 9(1), p. 19-46.

The Builder (1870). The Workman and his Fine Art. 28(1424), p. 402-403.

Cetera, A. (2008). Chelsea Academy, Lots Road, SW10, Archaeological Evaluation Report. Museum of London Archaeology Service, London.

Downing, A.J. (1856). Rural Essays. Leavitt and Allen, New York.

Fearing, A. (1917). Cottage Ornaments by Ralph Wood. The New Country Life 31(April), p. 82-

86.

Grand, S. (1894). Our Manifold Nature: Stories from Life. D. Appleton and Company, New York.

Grier, K. C. (1999). Childhood Socialization and Companion Animals: United States, 1820-1870. Society and Animals 7(2), p. 95-120. 
Hale, Mrs. (1868). Manners; or, Happy Homes and Good Society all the Year Round. J.E. Tilton and Company, Boston.

Holder, N., and Jeffries, N. (In prep). Spitalfields: the development of the London suburb from 1539 to the 1880s, Archaeological excavations at Spitalfields Market 1991-2007, volume 4. Museum of London Archaeology, London, UK.

Howells, W.D. (1889). A Hazard of New Fortune. Boni and Liveright, New York.

The Horticulturist. (1846). On Simple Rural Cottages. The Horticulturist 1(3), p. 105-110.

Jeffries, N. (2006). The Metropolis Local Management Act and the archaeology of sanitary reform in the London Borough of Lambeth 1856-86. Post-Medieval Archaeology 40(2), p. 272289.

Jekyll, G. (1904). Old West Surrey: Some Notes and Memories. Longmans, Green, and Company, London.

Leigh, E. (1859). Pets. Longman, Brown, Green, Longmans, and Roberts, London gilded age. International Journal of Historical Archaeology, 16(4), 745-760. http://dx.doi.org/10.1007/s10761-012-0206-x 
Leone, M.P. (1992). Epilogue: The Productive Nature of Material Culture and Archaeology. Historical Archaeology 26(3):130-133.

Leone, M.P. (1998). Symbolic, Structural, and Critical Archaeology. In Whitley, D.S. (ed.), Reader in Archaeological Theory, p. Post-Processual and Cognitive Approaches, Routledge, New York, pp. 49-68.

Mayhew, H. (1851). London Labor and the London Poor. Vol.1: The London Street Folk. Harper and Brothers, New York.

Mills, R. (2010). Miniatures in Historical Archaeology: Toys, Trifles, and Trinkets Re-Examined. Master's Dissertation, School of Archaeology and Ancient History, University of Leicester, Leicester, UK.

Mills, V. (2008). Introduction: Victorian Fiction and the Material Imagination. 19: Interdisciplinary Studies in the Long-Nineteenth Century http: //nineteen.cch.kcl.ac.uk/index.php/19/index Accessed March 11, 2011. gilded age. International Journal of Historical Archaeology, 16(4), 745-760. http://dx.doi.org/10.1007/s10761-012-0206-x 
Old Bailey Proceedings. (1825). Trial of Sophia Slaughter, Ann Slaughter, and William Gerrard, Grand Larceny $8^{\text {th }}$ December, 1825 (t18251208-153). www.oldbaileyonline.org, Accessed June 3, 2011.

Orvell, M. (1989). The Real Thing: Imitation and Authenticity in American culture, 1880-1940. University of North Carolina Press, Chapel Hill.

Parrington, V.L. (1927) Main Currents in American Thought. Harcourt Brace and Company, New York. Electronic version http://xroads.virginia.edu/ hyper/parrington/vol3/toc.html, accessed March 24, 2011.

Pascoe, C.E. (1885). London of To-Day. Roberts Brothers, Boston.

Pykett, L. (2003). The Material Turn in Victorian Studies. Literature Compass 6(20):1-5.

Richards, T. (1990). The Commodity Culture of Victorian England: Advertising and Spectacle, 1851-1914. Stanford University Press, Stanford, California.

Robie, V. (1912). By-Paths in Collecting. The Century Company, New York. gilded age. International Journal of Historical Archaeology, 16(4), 745-760. http://dx.doi.org/10.1007/s10761-012-0206-x 
Sankey, D. (1993). Site of former Albion Brewery, Whitechapel Road, E1, Site Code: ABR93. Museum of London Archaeology Service, London.

Saxby, D. (1997). Jacob's Island, bounded by Mill Street, George Row, Jacob Street and Bermondsey Wall West, SE1, Site Code: JAC96. Museum of London Archaeology Service, London.

Tyler, K. (2004). Two centuries of rubbish: excavations at an 18th and 19th century site at 12-18 Albert Embankment, Lambeth. Surrey Archaeological Collections 91, p. 105-136.

Veblen, T. (1899). The Theory of the Leisure Class: An Economic Study of Institutions. $6^{\text {th }}$ ed. MacMillan Company, New York.

Wharton, E. and Codman, O., Jr. (1897). The Decoration of Houses. Charles Scribner's Sons, New York.

Whitton, T.M. and Sons. (1899). Special Descriptive Circular of New Goods \& Leading Lines for Autumn and Christmas Trade, 1899. T.M. Whitton and Sons, London.

Author's version. Final version published as:

Mullins, P.R., \& Jeffries, N. (2012). The banality of gilding: Innocuous materiality and transatlantic consumption in the gilded age. International Journal of Historical Archaeology, 16(4), 745-760. http://dx.doi.org/10.1007/s10761-012-0206-x 